\title{
THE CONTRIBUTION OF HRD TO TOURISM-LED DEVELOPMENT IN AN AFRICAN CONTEXT
}

Y H Tecle ${ }^{1}$

Eritrean Ministry of Tourism, Asmara, Eritrea

J L Schroenn

School of Economics and Finance, University of KwaZulu-Natal, Pietermaritzburg

\begin{abstract}
The development potential of tourism is widely recognised, and its promotion has been embraced by many developing countries. While many African countries are among these, in most, tourism's potential remains underexploited. Africa's share of the global market remains low despite the region's advantages. Interlinked reasons for this commonly include poor service standards and a shortage of suitably skilled labour in the sector. Because human interaction forms a crucial component of any destination's tourism product, a country can enhance the economic contribution of tourism through the development of the people employed (or employable) in the industry, i.e. human resource development (HRD). This study uses concepts from management studies and economics to explore the links between tourism, economic development, and HRD, and highlights the role that tourism HRD can play in tourism-led development in an African context.
\end{abstract}

Abstract

JEL L83, O55

\section{1}

\section{Introduction}

The potential of tourism as a tool of development is widely recognised, and its promotion as such has been adopted by a great number of developing countries. While many African countries number among these, tourism's full potential in the continent commonly remains underexploited (Ashley \& Mitchell, 2006a). Interlinked reasons contributing to this frequently include poor service standards and a shortage of suitably skilled labour in the sector, despite high national unemployment levels. One way a country can enhance the economic contribution tourism can make is through the development of the people employed (or potentially employable) in the industry, i.e. human resource development (HRD). This study takes an interdisciplinary approach, drawing on important concepts from both management studies and economics to explore the links between tourism, economic development, and
HRD in the tourism sector. A case is made for increasing attention to HRD in tourism in a developing country context. Equipping people with the skills and attributes to enable them to take up the opportunities created by tourism can promote improved utilisation of a nation's human resources, alleviating poverty while in turn facilitating further growth in tourism.

The following section establishes a working definition of "tourism", and reviews the role of tourism in promoting economic growth and development. It highlights the still-low share of Africa in world tourism, and identifies some key features of employment in tourism that make HRD particularly pertinent to this industry. Section 3 turns to the concept of human resource development, defining this process in terms of its key aspects and noting its relationship to economic growth and development. Thereafter, the discussion turns to the relevance of HRD for tourism development. 


\section{2}

\section{Tourism and development}

\subsection{Defining "tourism"}

A review of the literature reveals that definitions of tourism vary considerably and are constantly evolving. As Tisdell and Roy (1998) point out, there has been some controversy about what constitutes both "the tourism industry" and a "tourist".

The definition of the tourism industry (or sector) is complicated by the fact that, unlike conventional industries, tourism does not produce a single, homogeneous product or service. Instead, it may be characterised as "industrial activity defined by the diverse collection of products (durables and non-durables) and services (transportation, accommodation, food and beverage, entertainment, government services, etc.) that are delivered to visitors" (WTTC, 2002: 25). It is helpful to distinguish, as the World Travel and Tourism Council (WTTC) does, between the tourism industry and the tourism economy. Because there is no single industry "supply side", both concepts infer supply-side equivalents from demand measures. The tourism industry is more narrowly defined and captures only the direct impact of travel and tourism activity, derived from the value of products and services consumed by visitors; the tourism economy captures the broader "economy-wide" direct and indirect impact of travel and tourism.

Regarding the definition of a tourist, Lea finds that the term "is capable of diverse interpretation with one survey of 80 different studies finding 43 definitions for the terms Traveller, Tourist, and Visitor" (Lea, 1993: 4). Some authors restrict the definition of tourism to numbers of miles away from home, or overnight stays in paid accommodation, while others consider only travel for the purpose of pleasure or leisure. A useful and comprehensive definition for the purpose of this paper is the one suggested by the World Tourism Organisation (WTO):

Tourism comprises the activities of persons travelling to and staying in places outside their usual environment for not more than one consecutive year for leisure, business, or other purposes not related to the exercise of an activity remunerated from within the place visited (Holloway, 1998: 2).

This definition implicitly subsumes day visitors or excursionists as tourists; this is considered appropriate for our purposes because most of the broad issues raised here apply no less to day visitors. In sum, a tourist is anyone who has travelled to a community but who does not plan to stay there on a permanent basis. Included as reasons for making tourist trips are vacations, sightseeing, business trips, visits to friends and relatives, attendance at conventions, special events such as festivals, and participation in a sports event.

The potential of tourism as a tool for economic growth and development - and its limitations and potential costs - are well-documented, and here we review only briefly how the development of tourism can contribute to economic development, citing recent international statistics to highlight the economic significance of this sector.

\subsection{Economic impact of tourism}

Tourism is one of the world's fastest growing industries. According to the World Tourism Organisation, in 2004, global international tourist arrivals reached 763 million, spending US\$623 billion (having increased from 394 million, spending US\$204 billion, in 1988); arrivals are predicted to reach 900 million by 2010 and over 1.56 billion by 2020 (WTO, 2004b and 2005). The travel and tourism economy accounts for around 10 per cent of global production, employment, consumer spending and capital investment (WTTC, 2002), and provides a major source of foreign exchange and tax revenue for many countries.

Not all regions and countries, however, benefit equally from tourism: the developed world reaps by far the larger gains. The highest share of international tourist arrivals is received by Europe (54.5 per cent in 2004), followed by Asia and the Pacific (20 per cent) and the Americas (16.5 per cent); Africa's share of arrivals remains far lower, accounting for 4.4 per cent in the same year (WTO, 2005). 
It is widely acknowledged that tourism growth is a pathway to economic development through its various contributions or impacts. The works of many authors, such as Tisdell and Roy (1998), Doswell (1997), Tribe (1999), Theobald (1998), and Davidson (1993), detail and discuss how tourism contributes to economic development through its employment generation, foreign exchange earnings, government revenues, multiplier effects, development of infrastructure, and development of entrepreneurial and other skills.

Many national leaders in developing countries have recognised tourism's economic significance; in the last two decades especially, there has been wider recognition among African countries of tourism's potential to contribute towards development (Rogerson \& Visser, 2004). The New Partnership for Africa's Development (NEPAD) recognises tourism as "one of the sectors with the most potential to contribute to the economic regeneration of the continent, particularly through the diversification of African economies, and generation of foreign exchange earnings" (2004, cited in Rogerson \& Visser, 2004: 3).

According to Ashley and Mitchell (2006a) tourism is more economically significant across a broader range of African countries than is commonly recognised. It currently makes important contributions to both GDP and employment in many African countries, as highlighted by these extracts from the WTTC League Tables (WTTC, 2002):

Travel \& tourism economy as percentage of GDP (2002)

$\begin{array}{llr}\text { Rank } & \text { Country } & \mathbf{\%} \\ 9 & \text { Seychelles } & 45.2 \\ 40 & \text { Namibia } & 13.6 \\ 84 & \text { Zambia } & 9.1 \\ 86 & \text { Lesotho } & 9.0 \\ 88 & \text { Kenya } & 8.7 \\ 106 & \text { Madagascar } & 7.5 \\ 112 & \text { South Africa } & 7.1 \\ 133 & \text { Swaziland } & 5.4 \\ 134 & \text { Botswana } & 5.4 \\ 136 & \text { Zimbabwe } & 5.3 \\ 157 & \text { Malawi } & 2.4\end{array}$

Travel \& tourism economy employment as percentage of total (2002)

$\begin{array}{llr}\text { Rank } & \text { Country } & \% \\ 40 & \text { Seychelles } & 14.1 \\ 47 & \text { Namibia } & 12.3 \\ 59 & \text { Madagascar } & 10.5 \\ 70 & \text { Zambia } & 10.0 \\ 79 & \text { Botswana } & 9.2 \\ 108 & \text { Zimbabwe } & 7.5 \\ 117 & \text { South Africa } & 6.9 \\ 121 & \text { Kenya } & 6.8 \\ 140 & \text { Swaziland } & 5.5 \\ 142 & \text { Malawi } & 5.5 \\ 147 & \text { Lesotho } & 5.0\end{array}$


Tourism also contributes substantially to exports across a range of African countries, accounting (in 2003) for over 25 per cent of exports in Morocco, Mauritius, and Tanzania; 17 per cent in Tunisia and Kenya; and 11-12 per cent in South Africa and Zambia. Although two-thirds of Africa's international tourism receipts accrue to just four countries (South Africa, Egypt, Morocco and Tunisia), tourism constitutes more than 10 per cent of exports for more than half the African countries for which there are data (Ashley \& Mitchell, 2006a).

Because tourism is a multi-disciplinary activity that involves several industries and draws upon a variety of skills, its benefits are spread over a wider section of society than is the case with other sectors. The stronger the linkages to other domestic sectors are, the greater is the positive impact of tourism on the development of a destination (Tisdell \& Roy, 1998; Ashley $\&$ Mitchell, 2006b). Recent research and policy have increasingly recognised tourism's potential to benefit poor people in particular, with the emergence of the concept of "pro-poor tourism". Ashley, Boyd and Goodwin (2000) find that tourism has an exceptional capacity to create opportunities for the poor, for several reasons. First, in tourism - unlike other 'export' industries - consumers' presence at the destination offers opportunities to sell additional goods and services. Second, tourism can diversify and bolster local economies; its benefits often reach the poorest areas of a country, precisely because these are least "developed", are often remote and have unspoilt natural and cultural resources. Furthermore, tourism is acknowledged to be relatively labour-intensive, and although tourism jobs encompass the spectrum of skills intensities, the relatively high proportion of low-skillsintensive jobs make this type of employment more accessible to previously disadvantaged or first-time employees (WTTC, 2002). Tourism also creates opportunities for small-scale enterprises, and typically employs a high proportion of women (Kaplan, 2004). These employment-related advantages of tourism as a vehicle of development and poverty alleviation are arguably its most significant: "it is known that the most important pro-poor impact of tourism results from the employment of local people in tourism establishments" (Ashley \& Mitchell, 2006a: 2).

The tourism and development literature highlights some potential negative impacts of tourism, such as environmental degradation and pollution and undesirable socio-cultural impacts at local or national level. Taking cognisance of the potential benefits as well as the possible costs, many developing countries are opting to follow policies promoting sustainable tourism, including rural tourism and eco-tourism, which causes little or no harmful impact, and generates increasing benefits to rural areas in terms of productivity, employment, improved distribution of wealth, conservation of the environment and culture, local people's involvement, and a suitable way of adapting traditional beliefs and values to modern times (Middleton \& Hawkins, 1998).

Indeed, it has been argued by many authors that tourism should lend itself to the concept of sustainable development because in so many cases, tourism growth depends upon maintenance of the natural environment, which is the resource base for its development (Wahab \& Pigram, 1997). Tourism can certainly contribute to environmental degradation and be selfdestructive; it also has potential to bring about significant enhancement of the environment (Pigram, 1993). For the tourism sector, the concept of sustainability implies meeting current uses and demands of tourism without impairing the natural and cultural heritage, or opportunities for collective enjoyment of tourists of the future (Hawickes \& Milhams, 1993 as cited in Wahab \& Pigram, 1997). This concept is particularly relevant for African countries, whose tourism potential is strongly based on natural and cultural resources. It is also closely tied to the principle of community involvement in the management of tourism resources, one of the key channels for ensuring that the benefits of tourism development reach the poor.

\subsection{Africa's recent tourism performance}

Although Africa has tremendous tourism potential, with a unique blend of natural and socio-cultural features that match the tastes of growing segments of the international tourism 
market (Cleverdon, 2002), its share of that market as revealed in statistics from recent years does not reflect these advantages: Africa received only between 3.6 and 4.5 percent of world international tourist arrivals and 2.0 to 2.9 percent of receipts during 1995-2004. Out of this, the larger share was claimed by North Africa (1.5 per cent of arrivals in 2001) and Southern Africa (1.2 per cent), while the remainder was attributed to East Africa (0.8 per cent), West Africa (0.4 per cent) and Central Africa (0.1 per cent) (WTO, 2002 and 2004a). The top three countries, namely South Africa (21.5 per cent), Tunisia (16.6 per cent) and Morocco (14.8 per cent), together received 52.9 per cent of all tourist arrivals to Africa in 2003. The top 10 - adding Zimbabwe (7.3 per cent), Algeria (3.7 per cent), Botswana (3.2 per cent), Kenya (3.0 per cent), Namibia (2.3 per cent), Mauritius (2.3 per cent) and Zambia (1.9 per cent) to the first three - altogether accounted for 76.7 per cent of the total tourism arrivals to Africa, while the ca. 35 remaining countries together accounted for less than 25 per cent (WTO, 2004a). This indicates that, for a variety of reasons, tourism is still a missed opportunity or unexploited potential resource for the majority of African countries.

However, there are indications that Africa has been gaining ground and may be able to benefit more significantly from future tourism expansion. From 1995-2000, Africa experienced an average annual growth rate of 6.3 per cent in international arrivals, higher than the global average of 4.8 per cent (WTO, 2002). In 2001, even though world international tourist arrivals and receipts reflected a negative trend from the previous year's figures (largely in the aftermath of the September 11 attacks on the USA), Africa showed an exceptionally positive trend of 4.3 per cent and 8.8 per cent for arrivals and receipts respectively, and continued to post above-average growth rates in 2002 and 2003, being largely unaffected by factors that dampened global tourism such as the Iraq conflict and SARS disease outbreak. Though undisputedly low, Africa's current 4.4 per cent share of world international arrivals represents a substantial improvement from 1.5 per cent in 1970; the percentage of arrivals may even be considered a success, given the continent's relative marginalisation in the world economy (reflected in its share of global exports of about 2 per cent) (Ashley \& Mitchell, 2006a).

The continent's share of international tourism receipts has not grown proportionately with its share of arrivals, fluctuating between 1.8 per cent and 2.9 per cent of the world total since 1995 (2.9 per cent in 2004 is the highest share recorded). Africa earned, on average, US\$550 per tourist arrival in 2004, which is substantially below the world average of US\$820, and is the lowest of all world regions (WTO, 2005). These figures suggest that Africa has been more successful in attracting greater numbers of tourists than it has in increasing the duration of visits or average spending of visitors. They reflect the relative inexpensiveness of Africa as a destination - an advantage which should favour further growth in arrivals. Low average expenditures also point to the limited range of products available, and the concomitant challenges and opportunities this presents to African countries.

The outlook for continued growth in tourism to Africa is favourable. The WTO (2005), in its Tourism 2020 Vision, expects Africa to record an average annual growth rate in international arrivals of 5 per cent for the period 1995-2020, compared with a world average of 4.1 per cent. Ashley and Mitchell (2006a) agree that Africa is likely to experience continued tourism growth in absolute and relative (market share) terms. Among reasons mentioned are its lower population density relative to Asia and Latin America that mean that demographic pressure on natural areas is lower (boosting Africa's advantages as an ecotourism destination). Also tourism from the developed world to "exotic" locations like Africa has a high income elasticity of demand, so should grow strongly as incomes in developed countries grow.

However, a range of issues or problems will have to be addressed before the continent can realise more of its tourism potential. Some are country-specific, while many are common to most African countries. This study has not set out to identify those problems or to characterise different countries' situations in any detail. Cleverdon's (2002) review of tourism opportunities and challenges in the 
SADC region notes some significant constraints hindering tourism development, which are likely to apply to varying degrees in all African countries. These include: health concerns (malaria and AIDS); access difficulties and infrastructure deficiencies; susceptibility to an uncertain investment climate; poor planning and weak institutions; safety and security concerns; political and economic instability; inadequate product development and marketing; and, of direct relevance to this study, HRD needs.

The following section considers the distinctive nature of tourism employment, to explain why "(o)ne of the biggest challenges for any destination seeking to develop its tourism sector is the provision of manpower with suitable skills and in sufficient volume" (Cleverdon, 2002: 16).

\subsection{The nature of tourism employment}

Tourism, more than most other sectors, is labourdependent. The quality of service provided in tourism establishments is a critically important component of a destination's tourism product. Moreover, happy customers, in this case tourists, are not only return customers, but will also pass on their best memories and experiences to others; offering superior service is thus a way of promoting the tourism product. A unique combination of characteristics of the tourism industry makes HRD particularly pertinent for this sector, and dictates the types of HRD that will be required.

\section{Employment characteristics}

Direct employment in tourism encompasses the range of work done by people in the establishments that provide goods and services to tourists prior to their departure from home, during travel as well as during their stay at their destination (i.e. the tourism "industry" as defined in 2.1 above). Davidson (1993) identifies the following special characteristics of tourism employment:

Shift and overtime work: Hours of work are often outside the normal office hours, and can be long and irregular.

Seasonality in demand: Often, the tourism sector suffers from seasonal fluctuations in demand. This creates a lack of continuity in operation, and employment in tourism may fluctuate between on and off seasons.

Contacts with non-local residents: Most of the time customers in tourism are non-locals who are on vacation, on business or visiting friends and relatives. Tourism workers are in regular contact with visitors from outside their region or country. One of the key implications of this is the need for multi-language proficiency.

Enjoyment for others: Tourism staff work in the sphere of providing enjoyment for others. They are expected to work hard to receive, feed, entertain, inform and clean up for tourists of heterogeneous nationalities, status, occupation, culture, gender, and religion, who may not always be polite or pleasant to deal with. They are therefore required to possess patience and tolerance.

Davis et al. (1999: 203, cited in Harrison, 2001), elaborate on some of the difficulties affecting tourism employment, including the nature of tourism employment (which is often unskilled, seasonal, part-time, or casual), the typically low pay levels, and the inadequate training workers receive. These features present challenges to human resource managers, because tourism tends to be viewed as "an industry lacking a firm career structure, being an employer of temporary staff, who tend to be working there while looking for a real job."

\section{Attitudes and feelings in tourism}

Attitudes and feelings are particularly important in tourism: the industry is centred on hospitality, which involves significant exchanges of feelings between host and guest. The warmth and concern of the server are critical components of quality service, and in this regard the employee's personal feelings and attitudes may be an important factor in determining how that employee functions in relation to the guest (Hartline \& Ferrell, 1996). Such attitudes are most significant when displayed by workers responsible for delivery of front-line tourism services (and are thus related to the question of language proficiency). The issue is so important that initiatives in many countries involve investing heavily in programmes that 
pay attention to "professionalisation" of the industry, and to socialising tourism workers and the wider community to the importance of tourism. As Davidson argues, the people who work in tourism are the key factors in the success of that industry: "attractive hotels, excellent transport networks, and a number of interesting things to see and do will not, by themselves, succeed in attracting tourists if the people working in the industry do not come up to the tourists' expectations" (Davidson, 1993: 191).

\section{Reward; recognition and motivation}

A further consideration is the issue of reward, recognition and employee motivation. For the individual worker, the delivery of quality service is based on motivation. Motivation is shaped in part by attitudes. It is also influenced by jobholders' perceptions of their treatment by the organisation. Workers can be motivated by pay, but can also be made more satisfied and productive by increased recognition and appreciation. Managers should also pay attention to issues of equity (in terms of pay as well as working conditions, supervision, promotion rules etc.), since there may be a relationship between contact employees' perceptions of fairness and their customer service behaviours (Bettencourt \& Brown, 1997).

\section{Tourism skills and requirements}

Satisfactory or superior service in the tourism sector - and the training necessary to ensure such service is provided - can be seen to encompass three necessary dimensions: technical, linguistic and social (Cleverdon, 2002). Davidson (1993) suggests tourism workers need to demonstrate certain skills (the first two below clearly being more occupation-specific, and the latter two more generic requirements of tourism staff):

Occupational skills: These are the basic skills that enable people working in tourism to do their jobs competently - e.g. a waiter must know how to take orders from tourists and how to serve food and beverage; a chef must be able to cook; a marketing specialist must know how to market the products.

Information skills: Tourists need information on a variety of topics such as travel directions, explanations of unfamiliar items on menus, local activities and places of interest, and information on the history and traditions of places they are visiting. Tourism staff should be ready to provide tourists with such information confidently and accurately.

Customer relations skills: These are skills related to making tourists feel comfortable or welcome, properly looked after, and confident that they are receiving the standard of service they expect. They expect the tourism staff to be cheerful, polite and helpful at all times. Customer relations skills also include the ability to deal with complaints.

Foreign language skills: Most of the time tourists are not expected to know the national or local language - this is particularly true for Africa and its main source markets in Europe, Asia and the Americas. Tourism staff should at least know internationally spoken languages and/or other languages of the majority of visitors to the tourist destinations.

In order to meet the expectations of tourism or to offer superior service, the whole range of tourism staff, employers and other stakeholders should be equipped with the necessary skills and attitudes. All of these requirements and issues can be addressed as part of a process of HRD, to which we turn in the following section.

\section{3}

\section{HRD and tourism development}

As discussed, tourism development can contribute significantly to economic growth, employment and poverty alleviation. Tourism's job-creation potential is especially relevant to developing countries, which are typically characterised, on the one hand, by a high rate of unemployment, and on the other, by an acute shortage of skills. HRD can play a strategic role in enhancing the quality of labour as a factor of production, facilitating the filling of jobs with suitably qualified workers, enabling people to take up opportunities created by tourism growth which might not otherwise have been open to them, and thus maximising the realisation and spread of the economic benefits of tourism. 
Before turning to look at the role of HRD in economic development in general and tourism development in particular, it is worth developing a deeper understanding of what is meant by this term.

\subsection{Defining "human resource development"}

HRD may be broadly defined as "the process of increasing the knowledge, the skills, and the capacities of all the people in a society. In economic terms, it could be described as the accumulation of human capital and its investment in the development of an economy" (Harbison \& Myers, 1964: 2).

Baum (2000: 288) elaborates, describing HRD as:

a continuous process or virtuous circle which uses investment in human capital in order to improve productive output, enhance the quality of that output, provide increased benefits for those employed and contribute to an improved quality of life for those involved and their dependants. At the same time, HRD is a process which is at the core of an organisation's investment in its human capital and, as such, can make a significant contribution to improved performance, productivity and profitability.

HRD is thus commonly defined as bringing quantitative and qualitative enhancement to human resources as a factor of development, so as to increase performance and productivity. It includes education, training, organisational development and career development, and also encompasses improvements in the health of the working population through better public health programmes and improvements in nutrition, which increase the working capacity of people. For our purposes, HRD is taken as referring to the integrated use of education and training to develop the productive capacity of individuals, groups, organisations and institutions. The other aspects of HRD, though important, will not be considered here.

The HRD process may be formal, such as in publicly accredited education or training courses, or it may take place in a range of informal situations. Formal HRD includes general and vocational education at schools and tertiary institutions, and programmes located within the organisation (e.g. on-the-job training and the workplace classroom). HRD has an important role to play on (or before) an individual's entry into a company through induction training; it has equal applicability (with different focus) for junior, entry level positions and senior managers, and is central to individual and organisational development (Baum, 2000: 289). Human resources are also developed in many less formal ways, including job experience and self-development (correspondence or selfreading). All of these components improve the efficiency and effectiveness of the workforce.

\subsection{Economic impact of HRD}

By enhancing a nation's labour resources, HRD has an impact on economic development. This relationship between human capital investment and economic growth can be couched in terms of human capital theory as propounded by Schultz (1961, 1963), Becker (1964) and others. Human capital theory focuses on the need to invest in people in order to achieve and sustain competitive advantage. Inefficient use of available human resources will increase labour costs, which will result in higher production costs. Therefore, in order to remain competitive in the market, it is imperative for a nation to pay special attention to developing its human resources. Investment in human capital enhances the ability of people to use their natural skills and ingenuity, and creates positive externalities. By raising the average quality of labour, increased education in turn increases employability and thus plays a significant role in the growth of national income.

Harbison and Myers (1964: v) emphasise the role of human resources in development, saying that "the building of modern nations depends upon the development of people and the organisation of human activity. Capital and natural resources play an important role in economic growth, but none is more important than manpower." Rosegger (1966: 45) agrees that "people's education and training, and, with these, their ability to adopt easily and 
flexibly, and technological changes are the key to improvement in real output." Human capital is thus a critically important factor affecting development and social progress. As Harbison and Myers (1964: 13) explain, "countries are underdeveloped because most of their people are underdeveloped, having had no opportunity for expanding their potential capacities in the services of society."

By creating opportunities for upward mobility, HRD also serves to reduce social stratification and tensions. Furthermore, in high population growth countries, HRD contributes to population control because acceptance of smaller families comes with higher levels of education (Harbison \& Myers, 1964).

The link between a country's potential for economic growth and higher employment, and its capacity to develop the skills and knowledge of its population, is now recognised by most governments as well as by all major international agencies. Although in a broader sense this link is not a new discovery, some researchers (for example Ashton \& Brown, 1999) see the new focus by governments on HRD as a fundamental shift in the conceptualisation of the links between economic growth and development, and the skills and knowledge of the workforce. This paradigm shift reflects the global view that a country's ability to achieve economic growth depends increasingly on its human resources, rather than its natural resources or physical capital (Harbison, 1973 in Todaro, 1992). Kaplan (2004) adds that the rationale for HRD goes beyond enhancing a country's competitiveness; the process is increasingly seen as an integral part of a larger development agenda that centres on poverty alleviation and job creation.

Adding a cautionary note, Todaro (1992) discusses the failure of the unrestrained and untargeted quantitative expansion of educational opportunities in the developing countries of Asia, Africa, and Latin America. Similarly, Ashton and Brown (1999) argue that an approach to HRD that focuses mainly on the supply of skills in the labour force is likely to have a limited impact, and could even be counter-productive by unduly raising people's hopes for employment (or better employment). Thus any programmes introduced should be thoroughly assessed and should also be demand driven. Training should be tailored to attain predetermined objectives and fill skills deficiencies or training gaps identified from training needs assessments. If HRD policies are unplanned and not supported by clear developmental objectives and skills requirements, they will simply divert scarce resources from socially productive activities, such as direct employment creation, and thus hinder rather than promote national development (Rosegger, 1966).

A significant aspect of human capital theory is that the investment in knowledge, skills and health not only benefits the individual, but also increases the employers' and even a country's human capital resource pool and potential productivity. However, despite the benefit that employers are able to realise from supporting the education of their current and potential employees, they are often reluctant to pay for this training due to the possibility of some employees manipulating the situation for free training. Often, the responsibility for increasing one's human capital still rests largely with the individual (Ehrenberg \& Smith, 2000). It is helpful to distinguish between two types of human capital investment: specific (training applicable to one firm only) and general (training applicable to many firms). Individuals and corporations have to evaluate the benefits and disadvantages of each type, based on their individual requirements and goals. Employers may be more willing to pay for specialised training, since the benefits of general training, which is readily transferable to another employer, are more likely to be lost to them. Conversely, the employee may be willing to pay for general training, as the skills acquired can be applied to many alternative employment situations. The public sector is clearly an important source of HRD funding, given the external benefits HRD can generate. Employers and their organisations can also influence the education and training of the current and potential future workforce by contributing to the formulation of policies promoting investment in education and training at all levels (Becker, 1964). 


\subsection{The importance of HRD in tourism}

Human capital is regarded as one of the pillars on which tourism development rests (WTO, 2000), and the importance of HRD is likely to increase as global tourism evolves over time. The pivotal role of host-guest interactions in tourists' experiences means that the quality of service has always been a crucial component of the tourism product, and this in itself makes HRD necessary: "It is an established fact that quality services can only be provided by quality education and training. Education brings knowledge and training provides skills: out of knowledge and skills, attitudes are borne and actions always flow from well-established attitudes" (WTO, 2000: 1).

Moreover, the global tourism scenario and the profiles and tastes of tourists are evolving rapidly. Two features of global tourism, which have emerged in the recent past and are likely to be permanent, are the adoption and application of new technology, and greater emphasis on quality (WTO, 2000). Both of these developments clearly add weight to arguments for increased attention to HRD. Wahab and Pigram's assertion (1975: 278) is more relevant than ever:

(T)ourism is becoming a complicated developmental sector which requires expertise and professionalism. Tourism's multifaceted function, as a socio-economic and politicocultural phenomenon, as a complex industry, and as a profession having its own rules and codes of ethics, requires a broad intellectual background and specialised education and/ or training to enable its policy makers and professionals to keep abreast of the scientific and technological changes as well as to challenge the fierce competition.

This evolution of tourism also points to the importance of providing for re-training of tourism workers, because basic and once-off training will not be adequate for the needs of this rapidly changing context.

The traditional constraints of the hotel, catering and tourism industry - long, antisocial working hours, low pay, unstable, seasonal employment and low job status - make employment within the industry appear unattractive to many. The immediate and most obvious consequences of such a situation are the difficulty in recruiting suitable staff, and high staff turnover; both these effects are costly to the industry. There is thus a need for HRD to raise the profile of the industry, increase productivity and provide decent, sustainable employment within the sector (Harrison, 2001), as well as enabling staff who start in unskilled or semi-skilled jobs to move up the management chain (Ashley \& Mitchell, 2006b).

On a macro level, human resources deficiencies that remain unaddressed will constrain the sector's growth: "lack of trained and skilled manpower could deal a significant blow to the growth of tourism owing to its labour-intensive nature... Accelerated tourist growth rates projected for the New Millennium call for an equally accelerated preparedness with respect to workforce... (if countries are) to be in a position to face the challenges posed by the expected growth rates" (WTO, 2000: 1).

Inadequate human resources can perpetuate a country's reliance on expatriate labour, resulting in leakages of income, which significantly reduce the economic benefits of tourism. Conversely, at local level, employment is acknowledged as tourism's most important pro-poor impact in developing countries, because the nature of jobs created tends to favour the poor rather than the elite. Because wages earned by local staff are often the single largest cash flow from tourism to the local economy, increasing the recruitment, training and career progression of locals is an effective way of strengthening linkages and increasing the impact of tourism (Ashley \& Mitchell, 2006b).

Human resources constraints identified by the WTO in Asia and the Pacific region are also likely to apply in Africa. In addition to the shortage of skilled and trained manpower, which may limit the overall growth of the sector, issues that countries must address include inadequate supply of trainers and teaching staff; the low priority accorded to tourism education and training by both public and private sectors; and the negative attitudes of employers to tourism education and training because of the commercial nature of their operations 
(WTO, 2000). Unless governments intervene to overcome these constraints, countries will not be able to derive the maximum benefit from tourism growth.

Cleverdon (2002) finds that the shortage of suitably qualified and experienced staff affects all aspects of tourism in almost all SADC countries. Areas of shortfall he identifies range from government officials to indigenous businesspeople in both SMMEs and larger corporations, to communities and residents, and to skilled workers employed in tourism. $\mathrm{He}$ argues that action is needed on several fronts, from the inclusion of tourism in school curricula to create basic tourism awareness, to the provision of higher education for tourism decision-makers, and notes that a number of African countries are currently examining how to meet these needs.

Public sector support for HRD in tourism is justified by "the need to ensure minimum operating and service standards throughout the destination's supply chain" (Baum, 2000: 290). Examples of such support, both financial and practical, abound in successful tourism destinations. In addition to direct public provision of education and training, incentives can be offered to companies to invest in HRD, for instance by means of payroll levy schemes, subsidised training provision, and tax exemptions. At a more basic level, there is a growing recognition that awareness of tourism and its generic skills needs (such as customer care and quality) should be developed in the general population at a young age. These elements are increasingly included in primary and secondary school curricula internationally; this practice can be seen as the starting point for HRD in tourism. Beyond this, the details of HRD programmes in any country should be determined on the basis of thorough needs assessments, to identify areas of shortfall and decide on the most effective ways of redressing them. Ongoing evaluation and reassessment of the state of the industry's human resources is needed to ensure that tourism growth can be sustained.

\section{South Africa's tourism HRD situation}

Though the intention of this paper is not to undertake a formal analysis of the state of tourism human resources in any African country, South Africa's experience provides a salient illustration of human resource shortcomings acting as a brake on tourism success and is worth reflecting on briefly. The rapid growth in tourism to South Africa after 1994 strained the ability of the country's training resources to meet the requirements for trained staff in the tourism sector; the Tourism Cluster Consortium's report (1999, cited in Cleverdon, 2002: 17) found that personnel shortcomings prevented some components of South Africa's tourism industry "from becoming internationally competitive due to a perception that it does not reach international expectations in product quality and service levels".

Furthermore, Pillay (2003) states that the skills intensity of South Africa's tourism sector has increased, and that employers have adopted more capital-intensive methods and substituted part-time or casual employees for full-time in response to labour market regulation. Though the proportion of unskilled employment is still relatively high, these trends underline the need for increased attention to skills development and training.

The establishment of THETA (the Education and Training Authority responsible for skills development in the tourism and hospitality sector) and the National Skills Development Levy System (in terms of which employers pay a percentage of their payroll as a levy, most of which is reclaimable if they invest in staff education and training) was hailed as one of the best ways for government to promote tourism HRD (WTTC, 2002), but it does not appear to be working effectively. Many employers apparently simply pay the levy as a tax, submit skills development plans but do not actually carry out any accredited training (National Labour and Economic Development Institute, 2003). Moreover, a huge number of tourism operations - informal and small businesses - fall outside of THETA's defined scope or below the skills levy threshold, so are not subject to its influence or to the funding incentive to provide training.

Kaplan (2004) finds that THETA has been more successful at promoting equality within the existing formal tourism industry than at supporting the development of emerging forms 
of tourism. Yet, as she argues, many new tourism developments in this country - and those with the greatest potential to alleviate poverty, such as cultural, heritage and nature-based tourism will occur outside the mainstream, at community level. Growth of this type of tourism remains constrained by a lack of appropriate knowledge and skills.

HRD is crucial for transformation and black economic empowerment in the tourism sector in this country. Rogerson (2004) points out that recent research among tourism firms reveals high degrees of compliance with the Employment Equity Act (in terms of which all South African companies with over 50 employees must draw up employment equity plans and targets to increase the total number of black employees and the proportion in senior and middle management), but slow progress in the advancement of black staff because of skills deficiencies.

In sum, although the government has been addressing the skills shortage through several initiatives, including some of the mechanisms mentioned in the previous section, the deficit persists, and is widely agreed to be the biggest challenge facing tourism in this country (Njobeni, 2006; Mosola, pers. com. in Shevel, 2005). Kaplan (2004) finds that although policymakers have a pragmatic view of tourism as a tool of development, there is a lack of an integrated and coordinated approach to skills development in tourism, which seriously limits its potential to impact positively on transformation and development in South Africa.

\section{4}

\section{Conclusion}

African countries in general are frequently characterised by superb tourism potential, together with urgent development imperatives. Tourism has increasingly come to be recognised as an effective strategy for development, job creation and poverty alleviation, but its potential remains unrealised across most of the continent. The prospects for future tourism growth in Africa are favourable, but may be constrained by a range of factors, including quantitative or qualitative human resources shortcomings.
This paper has set out to draw attention to the importance of tourism HRD, and to explore how this process can unlock the potential of tourism to contribute to economic growth and upliftment with reference to African countries. As we have seen, HRD, especially with regard to education and training, contributes to economic development in terms of increased worker productivity and income. HRD is of particular importance in the tourism sector, because human interactions, as embodied in service standards, are a central component of the tourism product. From the perspective of local economies, tourism HRD is an effective way of boosting the beneficial impacts of employment of local people.

The extent to which a nation realises its potential for economic growth and development to a large degree depends on its ability to develop and utilise the innate capacities of its people effectively. Regarding tourism, it is the efforts of the people employed in the sector that will have to mobilise capital, utilise natural resources in a sustainable way, create markets and promote a country as a tourist destination. The efficiency and effectiveness of their work depends on their knowledge, skills and attitudes. Appropriate HRD, designed on the basis of comprehensive and ongoing HR needs analysis and implemented as part of broader development strategies, will thus be pivotal to the success of further tourism development in African countries.

\section{Endnotes}

1 The research funding support provided by Asmara University National Human Resource Development Project is gratefully acknowledged.

\section{References}

1 ASHLEY, C.; BOYD, C. \& GOODWIN, H. (2000) "Pro-poor tourism: Putting poverty at the heart of the tourism agenda", Natural Resource Perspectives No. 51, Department for International Development: London.

2 ASHLEY, C. \& MITCHELL, J. (2006a) Can Tourism Help Reduce Poverty in Africa? Overseas Development Institute (ODI) Briefing Paper, ODI: London. 
3 ASHLEY, C. \& MITCHELL, J. (2006b) “Tourism business and the local economy: Increasing impact through a linkages approach", Overseas Development Institute (ODI) Briefing Paper, ODI: London.

4 ASHTON, D.N. \& BROWN, P. (1999) Education, Unemployment and Labour Markets, Falmer: London.

5 BAUM, T. (2000) "Human resource development", in J. Jafari (ed.) Encyclopedia of Tourism, Routledge: London.

6 BECKER, G.S. (1964) Human Capital: A Theoretical and Empirical Analysis with Special Reference to Education, National Bureau of Economic Research and Colombia University Press: New York.

7 BETTENCOURT, A. \& BROWN, S.W. (1997) "Contact employees: Relationship among workplace fairness, job satisfaction and prosocial work behaviours", Journal of Retailing, 73(1): 3961.

8 CLEVERDON, R.G. (2002) “Tourism development in the SADC region: The opportunities and challenges", Development Southern Africa, 19(1): 7-28.

9 DAVIDSON, R. (1993) Tourism, Pitman Publishing: London.

10 DOSWELL, R. (1997) Tourism: How Effective Management Makes the Difference, ButterworthHeinemann: Oxford.

11 EHRENBERG, R.G. \& SMITH, R (2000) Modern Labour Economics: Theory and Public Policy, Addison-Wesley: Oxford, Ontario.

12 HARBISON, F.H. \& MYERS, C.A. (1964) Education, Manpower, and Economic Growth: Strategies of Human Resource Development, McGraw Hill: New York.

13 HARRISON, D. (2001) Tourism and the Less Developed World: Issues and Case Studies, CABI Publishing: New York.

14 HARTLINE, M.D. \& FERRELL, O.C. (1996) "The management of customer contact service employees: An empirical investigation", Journal of Marketing 4(2): 240-248.

15 HOLLOWAY, J.C. (1998) The Business of Tourism ( $5^{\text {th }}$ ed.) Addison Wesley Longman: Harlow.

16 KAPLAN, L. (2004) "Skills development in tourism: South Africa's tourism-led development strategy", GeoJournal, 60 (3): 217-227.

17 LEA, J.P. (1993) Tourism and Heritage Attractions, Routledge: London.

18 MIDDLETON, V. \& HAWKINS, R. (1998) Sustainable Tourism, Butterworth-Heinemann: Oxford.
19 NATIONAL LABOUR AND ECONOMIC DEVELOPMENT INSTITUTE (NALEDI) (2003) Work Re-organisation and Industrial Relations in the Tourism Industry: A research report for NALEDI, (online) available: http://www.naledi. org.za/docs/hosp3.pdf.

20 NJOBENI, S. (2006) "Tourism body needs revamp for 2010”, Business Day, 10 August 2006.

21 PIGRAM, J. (1993) Outdoor Recreation and Resource Management, Croom Helm: London.

22 PILLAY, P. (2003) "Chapter 4: The skills requirements of specific economic sectors", in Human Sciences Research Council (HSRC), HRD Review, HSRC: Pretoria.

23 ROGERSON, C.M. \& VISSER, G. (2004), "Tourism and development in post-apartheid South Africa: A ten year review”, in C.M. Rogerson and G. Visser (eds.) Tourism and Development Issues in Contemporary South Africa, Africa Institute of South Africa: Pretoria.

24 ROGERSON, C.M. (2004), "Black economic empowerment in South African tourism", in C.M. Rogerson and G. Visser (eds.) Tourism and Development Issues in Contemporary South Africa, Africa Institute of South Africa: Pretoria.

25 ROSEGGER, G. (1966) The Economics of Production and Innovation: An Industrial Perspective ( $3^{\text {rd }}$ ed.) Butterworth; Oxford.

26 SCHULTZ, T.W. (1961) "Investment in human capital", American Economic Review, 51: 1-17.

27 SCHULTZ, T.W. (1963) The Economic Value of Education, Colombia University Press: New York.

28 SHEVEL, A. (2005) "Tourists rekindle love affair with SA”, Sunday Times, September 182005.

29 THEOBALD, W.F. (1998) Global Tourism (2 $2^{\text {nd }}$ ed.) Butterworth-Heinemann: Oxford.

30 TISDELL, C.A. \& ROY, K.C. (1998) Tourism and Development, Nova Science Publishers: New York.

31 TODARO, M.P. (1992) Economics for a Developing World ( $3^{\text {rd }}$ ed.) Longman Publishing: New York.

32 TRIBE, J. (1999) The Economics of Leisure \& Tourism ( $\left.2^{\text {nd }} \mathrm{ed}.\right)$ : Butterworth-Heinemann: Oxford.

33 WAHAB, S. \& PIGRAM, J. (1997) Tourism, Development and Growth: the Challenge of Sustainability, Routledge: London.

34 WORLD TOURISM ORGANIZATION (WTO) (2000) "Tourism challenge in the $21^{\text {st }}$ century - $H R D$ in Asia and the Pacific", (online) available: http:// www.world-tourism.org/isroot/wto/pdf/1171-1.pdf.

35 WORLD TOURISM ORGANIZATION (WTO) (2002) Tourism Market Trends, Africa, 2002 Edition, WTO: Madrid.

36 WORLD TOURISM ORGANIZATION (WTO) (2004a) “Tourism highlights 2004 edition", (online) 
available: http://www.world-tourism.org/facts/ highlights/HIGHLIGHTS\%20INGLES\%2020041. pdf.

37 WORLD TOURISM ORGANIZATION (WTO) (2004b) "News Release 21 October 2004: WTO Policy Forum: Tourism is top priority in fight against poverty", (online) available: www.world. tourism.org/newsroom/Releases/2004/october/ washington 2.htm.

38 WORLD TOURISM ORGANIZATION (WTO) (2005) "Tourism highlights 2005 edition", (online) available: http://www.world-tourism.org/facts/eng/ pdf/highlights/2005_eng_high.pdf .

39 WORLD TRAVEL AND TOURISM COUNCIL (WTTC) (2002) South Africa: The Impact of Travel and Tourism on Jobs and the Economy, WTTC:

London. 